\title{
Diets link metabolic syndrome and colorectal cancer development (Review)
}

\author{
JIRAKRIT SAETANG $^{1^{*}}$ and SURASAK SANGKHATHAT ${ }^{2 *}$ \\ ${ }^{1}$ Department of Biomedical Sciences, Faculty of Medicine, Prince of Songkla University; ${ }^{2}$ Tumor Biology Research Unit, \\ Department of Surgery, Faculty of Medicine, Prince of Songkla University, Songkhla 90110, Thailand
}

Received July 24, 2016; Accepted January 13, 2017

DOI: $10.3892 /$ or.2017.5385

\begin{abstract}
Diets have been believed to be an important factor in the development of metabolic syndrome and colorectal cancer (CRC). In recent years, many studies have shown an intimate relationship between mucosal immunity, metabolism and diets, which has led to a greater understanding of the pathophysiology of metabolic syndrome and CRC development. Although the precise effects of diets on oncogenesis have not been completely elucidated, microbiota changes and inflammation are believed to be important factors that influence the development of CRC. Moreover, increased release of pro-inflammatory cytokines and alteration of adipokine levels have been observed in patients with colorectal adenoma and/or CRC, and these all have been considered as the important mechanisms that link diets to the development of metabolic syndrome and CRC. Importantly, a high-fat, low-fiber diet is associated with dysbiosis, and as the gut signature becomes more important in metabolic syndrome and $\mathrm{CRC}$, an increased understanding of diets on bacterial activity in the pathogenesis of metabolic syndrome and CRC will lead to new preventive and therapeutic strategies.
\end{abstract}

\section{Contents}

1. Introduction

2. Metabolic syndrome is a brain-, inflammatory- and microbial -related disease

3. Colonic carcinogenesis may be promoted by diet-related carcinogenic metabolites

4. Adipocytokines link metabolic syndrome to the risk of CRC

5. Conclusion

Correspondence to: Dr Surasak Sangkhathat, Tumor Biology Research Unit, Department of Surgery, Faculty of Medicine, Prince of Songkla University, Hat Yai, Songkhla 90110, Thailand

E-mail: surasak.sa@psu.ac.th

*Contributed equally

Key words: colorectal cancer, metabolic syndrome, inflammation, gut homeostasis

\section{Introduction}

Visceral obesity or, in its broader terminology, metabolic syndrome is an emerging lifestyle-related health problem that has globally increased in prevalence in recent decades (1-5). Metabolic syndrome is clinically defined as a combination of visceral obesity, increased blood pressure, insulin resistance and dyslipidemia $(6,7)$. This condition has been extensively investigated due to its correlation with various health problems in humans, including cardiovascular diseases, type 2 diabetes (T2D) and non-alcoholic fatty liver disease. In addition to these diseases, which are directly related to visceral adiposity, recent studies have also explored other consequences of metabolic syndrome, such as thromboembolic conditions, hypogonadism and various cancers (8-11). Recent studies have suggested that the pathophysiology of metabolic syndrome is partly associated with dysfunction of the intestinal flora (12-14), a condition called dysbiosis (15). Both brain functions and gut microbiota influence fat intake and increased body mass, which in turn is a source of cytokines that induce chronic, low-grade inflammation and carcinogenesis (16-18). Additionally, obesity itself influences the ecology of the gut microbiota population (19).

Colorectal cancer (CRC) is one the cancers that has been associated with metabolic syndrome. CRC is an epithelial cell-derived adenocarcinoma that develops through a multistep carcinogenic process known as the adenoma-carcinoma sequence. Epidemiological studies have demonstrated that colorectal adenomas and CRC risk are higher in individuals with metabolic syndrome or any of its components (20-22). A recent meta-analysis of cohort studies reported that metabolic syndrome was associated with higher relative risks of CRC in men at 1.25 (95\% confidence interval; 1.19-1.32) and in women at 1.34 (1.09-1.64) (22). In recent decades, partly because of the improved resolution of high-throughput sequencing technology, the gut microbiome has been extensively investigated. Studies have suggested a link between diet-induced microbiota dysbiosis and colorectal carcinogenesis (22).

This review aims to update the current understanding of metabolic syndrome and its role as a pathogenic factor in colorectal pathogenesis. 
2. Metabolic syndrome is a brain-, inflammatory- and microbial-related disease

Metabolic syndrome as a brain disease. Obesity is a major risk factor for several types of cardiovascular and metabolic diseases, such as hyperglycemia, T2D, hypertension and atherosclerosis (23). Individuals with more than three of these symptoms with or without obesity are diagnosed with 'metabolic syndrome'. Although obesity and metabolic syndrome are generally considered a problem of the gut, neurobiological studies have shown that the brain also plays an important role since neurobiological diseases, such as stroke, dementia, intracranial hypertension and sleep disorders are associated with obesity (24). Moreover, obesity can be initiated by pathological conditions of the brain and several neuropsychiatric drugs $(25,26)$. Therefore, the brain appears to be a central regulator that directs energy fluxes within an organism.

According to the 'selfish brain theory' (27) which states that the human brain fulfills its own comparably high energy needs with the highest priority, there are three types of behavioral components regulated by the central nervous system for energy requests: allocative, ingestive and exploratory behaviors (28). The allocation of energy from the body to the central nervous system is the 'allocative behavior' carried out by organs such as the liver, pancreas, muscles and adipose tissue (28). The second strategy is 'ingestive behavior', describing a situation where the brain acquires energy from its immediate environment, which is initiated by sensory metabolic input signals, including leptin and insulin (28-30), and afferent nerve fibers $(31,32)$. The last component, exploratory behavior, enables foraging in distant locations when energy resources in the immediate vicinity become scarce. The brain integrates all three of these behaviors to introduce a feedback control for an 'energy on demand' process that maintains an adequate ATP concentration in the nerve cells of the brain. However, if this allocative behavior of the brain fails to satisfy its energy requirements, ingestive behavior increases, leading to the promotion of higher body mass.

Obesity development may be caused by this allocative defect, in which the brain requires energy from food consumption instead of blood sugar (28). The mechanism of this failure may result from an abnormality in various regions of the brain, such as the hypothalamus, amygdala or hippocampus. Clinical studies dating back more than a century have demonstrated that hyperphagia and obesity can be induced by lesions of the ventromedial hypothalamus (VMH), a part of the brain that plays a role in preserving body mass $(28,33)$. In animal studies, lesions of the VMH have caused weight gain in dogs, while VMH stimulation led to satiety $(28,34)$. It is possible that lesions of the VMH lead to increased parasympathetic activity, resulting in an inadequate allocation of glucose to the brain. Then, the animal becomes hyperinsulinemic, finally resulting in hypoglycemia, neuroglycopenia and excessive body mass (35-37). In addition, several defective signaling pathways in the hypothalamus have been reported to be involved in obesity development. For example, studies have shown that loss of the leptin receptors in the hypothalamus resulted in obesity, insulin resistance and diabetes in mice $(38,39)$. Leptin signaling abnormalities have also been found in obese patients and were caused by a monogenetic defect or a leptin receptor mutation in the hypothalamus $(40,41)$.

A regulator of insulin and leptin signaling, protein tyrosine phosphatase $1 \mathrm{~B}$, has also been associated with leptin and insulin resistance in hypothalamic neurons $(42,43)$ as neuronal protein tyrosine phosphatase 1B-knockout mice showed improved glucose tolerance following chronic high-fat feeding (44). Moreover, VMH lesions may be associated with an unusual vagus nerve-hypothalamus interaction pathway leading to miscommunication between the adipose tissue and $\beta$-cells (45). Other factors that result in obesity include a lack of $\alpha$-melanocyte-stimulating hormone (46), insulin (47) or interleukin-6 (IL-6) (48) or bilateral lesions of the amygdala $(36,49)$. However, not all obese individuals develop obesity due to lesions of the brain. The core concept of the selfish brain theory, the brain-pull hypothesis, posits that 'brain-pull' is the force with which the brain actively demands energy from the body (50), indicating that the brain has an active approach associated with specific brain-pull mechanisms (51). Stress has been suggested as the major mechanism that causes the brain to enter a hypervigilant state. This leads to an increased requirement for cerebral energy and initiation of brain-pull mechanisms $(52,53)$, such as 'cerebral insulin suppression' that over time results in the loss of subcutaneous adipose tissue, the accumulation of visceral fat and an increased cerebral glucose supply (51).

Metabolic syndrome as an inflammatory disease. Metabolic syndrome and obesity are related to a chronic, low-grade systemic inflammatory condition characterized by increasing levels of circulating inflammatory cytokines and free fatty acids (FFAs) (54). In contrast to classical inflammation, this 'metabolic inflammation' $(55,56)$ does not necessarily involve pathogens but occurs as a result of metabolic homeostatic abnormalities. Nowadays, obesity has been associated with inflammatory adipose tissue, which may be caused by higher immune cell accumulation in the fatty tissue region (57). The immune cells associated with this metabolic inflammation include macrophage, neutrophil and lymphocyte.

Adipose tissue macrophages (ATMs). ATMs appear to play a major role in the regulation of obesity-induced inflammation as ATMs generally play a key role in most cases of chronic inflammation, and these cells can comprise up to $40 \%$ of the cells in the adipose tissue (58). It is possible that obesity-induced inflammation is regulated by macrophages (59), and ATM accumulation can be found after as little as 1 week on a high-fat diet (60). Moreover, numerous studies have indicated that accumulation of monocytes and macrophages is positively linked to subcutaneous fat accumulation and weight gain (61). Elevated monocyte levels can be found in the circulation of obese individuals, and the levels decrease when the fat is lost $(62,63)$. These circulating monocytes can be attracted to recruit into the adipose tissue by macrophage chemoattractant protein-1 (MCP-1) (also as known as CCL2), which is secreted by enlarging adipocytes $(64,65)$. Interestingly, mice that lack CCR2, the receptor for MCP-1, showed a decreased food intake and obesity development and increased eosinophil accumulation, which highly increase the expression of IL-4 and IL-13 in the adipose tissue during high-fat diet feeding, leading to the predominance of M2 macrophages $(66,67)$. In addition to 
CCL2, other studies have found that CXCL12, CXCL14 and CCL5 also play roles in macrophage migration (68-70).

In the tissues, macrophages can be subgrouped into 2 types: the classically activated macrophages, termed M1 and the alternatively activated macrophages, termed M2 (71). The M1 macrophage is a CD11 ${ }^{+}$pro-inflammatory cell that produces inducible nitric oxide synthase and inflammatory cytokines, such as IL-6 and tumor necrosis factor- $\alpha$ (TNF- $\alpha$ ), while the M2 macrophages, which can be identified by the markers CD206, CD209 and CD301 (Mgl1/2), express arginase 1 (Arg1) and immunosuppressive cytokines, including IL-10, transforming growth factor- $\beta$ (TGF- $\beta$ ), IL-1 receptor antagonist (IL-1RA)- $\alpha$ and IL-4 (59). Interestingly, in obese adipose tissue, the production of anti-inflammatory IL-10 is decreased, and increased levels of inflammatory TNF- $\alpha$ are observed (72). This may be the obvious evidence showing the dominance of the pro-inflammatory macrophage in adipose tissue of obese person. However, recent study demonstrated that inflammatory ATMs found in obese adipose tissue have a uniquely distinct phenotype from M1 macrophages called 'metabolically activated (MMe) macrophages' (73), and this phenotype can be induced in vitro by treating macrophages with palmitate, insulin and glucose (metabolic activation) (73). While M1 macrophages display cellular markers CD319, CD274 and CD38, ATMs from obese individuals express lipid transport proteins ATP-binding cassette member 1 (ABCA1) and fatty acid translocase (CD36) (73). Although, both types of macrophages have different phynotypes, they still shared the pro-inflammatory properties by producing TNF- $\alpha$, IL- 6 and IL-1 $\beta$ (73).

Neutrophil. Neutrophils are granulocytes that carry a large number of granules (intracellular vesicles), which contain anti-microbial agents, including lysozyme, neutrophil elastase (NE), myeloperoxidase (MPO) and defensins (59). Although neutrophils are known to play a role in inflammation, it is still unclear whether this type of immune cells is involved in obesity-induced inflammation. Several studies have found that neutrophil migration into the adipose tissue and classical inflammation occurred within 3 days of beginning a high-fat diet in mice $(74,75)$. However, another study found that the neutrophils decreased after 1 week of high-fat feeding, which suggests that neutrophils may play different roles in different stages of obesity development. In this study, they appeared to induce early polarization of ATMs toward the M1 phenotype with corresponding increases in TNF- $\alpha$ and IL-6 (74). Increased percentages of peripheral blood neutrophils have also been found in obese males (76).

T lymphocyte. Lymphocytes are strongly associated with inflammatory processes in obesity. Although there are several lymphocyte cell types that are related to obesity and metabolic syndrome, pro-inflammatory Th1, Th17 and $\mathrm{CD}^{+} \mathrm{T}$ cells predominate over anti-inflammatory regulatory $\mathrm{T}$ cells (Treg) and Th2 cells, which are found in higher proportions in lean adipose tissue $(77,78)$. One study found that mice fed a high-fat diet displayed more Th1 polarization and interferon- $\gamma$ (IFN- $\gamma$ ) production, which occurred several months after macrophage accumulation and insulin resistance (79). However, the number of Treg cells was decreased in the adipose tissue of obese mice, but insulin sensitivity can also be improved when these cells are increased (78). An increased number of Th17 cells in the spleen has been found in mice fed a high-fat diet, but this cell was absent in $I L-6^{-/}$mice fed the same high-fat diet, indicating that IL-6 is important for Th17 expansion in obesity (80).

$\mathrm{CD}^{+} \mathrm{T}$ cells are another type of lymphocytes that may be involved in obesity development since co-cultures of splenic $\mathrm{CD}^{+} \mathrm{T}$ cells with adipose tissue from high-fat diet mice showed a higher proliferation rate of $\mathrm{CD}^{+} \mathrm{T}$ cells than those of the lean controls (81). Several studies have also found that higher numbers of $\mathrm{CD} 8^{+} \mathrm{T}$ cells were positively correlated with an increased risk of insulin resistance $(78,81,82)$. The recovery of $\mathrm{CD}^{+} \mathrm{T}$ cells in knockout mice exacerbated obesity-induced insulin resistance, and this was correlated with increased M1 macrophages and IL- 6 and TNF- $\alpha$ gene expression in adipose tissue (81).

$B$ lymphocyte. In addition to T cells, B cells have also shown a positive association with obesity in high-fat diet-fed mice because infiltration of B cells can be found in the adipose tissue of obese mice, and these cells can activate $\mathrm{T}$ cells and polarize macrophages toward the M1 type (83). One study found that the number of IgG-associated B cells increased rapidly after 4 weeks on a high-fat diet (84), and the cell numbers then remained consistent during the weight gain $(83,85)$. By using neutralizing antibodies against the B cells, other studies have found that obesity-induced insulin resistance in mice could be improved, and a reduction in M1 macrophages and activation of $\mathrm{CD}^{+} \mathrm{T}$ cells along with an increase in Treg numbers and M2 signatures could be observed in the adipose tissue $(83,86)$. Although B cells are associated with the inflammatory condition in obesity, regulatory B cells, which produce IL-10, have been shown to improve insulin resistance and reduce pro-inflammatory cytokine production in the skeletal muscles of mice fed a high-fat diet (83). These results support the findings from other studies, which found that low levels of IL-10 were associated with metabolic syndrome and T2D $(87,88)$.

Metabolic syndrome as a microbial-related disease. The human intestine contains a unique group of microorganisms comprising up to 1,000 different species with $\sim 100$ trillion cells of bacteria, yeasts and parasites (89). There are over 50 bacterial phyla that comprise the gastrointestinal (GI) microbiota, but $\sim 90 \%$ consists of Bacteroidetes and Firmicutes $(90,91)$, and diet is clearly seemed to be a major influence on microbiota compositions.

Various evidences have shown that alteration of the diet can result in changes in the bacterial composition that also affected gut metabolic activity, especially the production of short-chain fatty acids (Fig. 1) (92). This scenario can be found in obese individuals (93) as high-fat diets or diets low in fiber have been associated with a higher abundance of Firmicutes (94). Studies comparing obese individuals and their lean twins have also shown a higher predominance of Firmicutes and lower abundance of Bacteroidetes $(93,95)$ in the obese subjects. Other studies, however, have not found a difference $(96,97)$.

Alternatively, the association studies between gut microbiota in obesity and metabolic syndrome have been performed by using germ-free mice. Researchers found that conventionalization of germ-free C57BL/6 mice with normal microbiota harvested from conventionally raised, genetically obese mice resulted in $60 \%$ higher levels of body fat and the development of insulin resistance in 2 weeks, despite reduced 


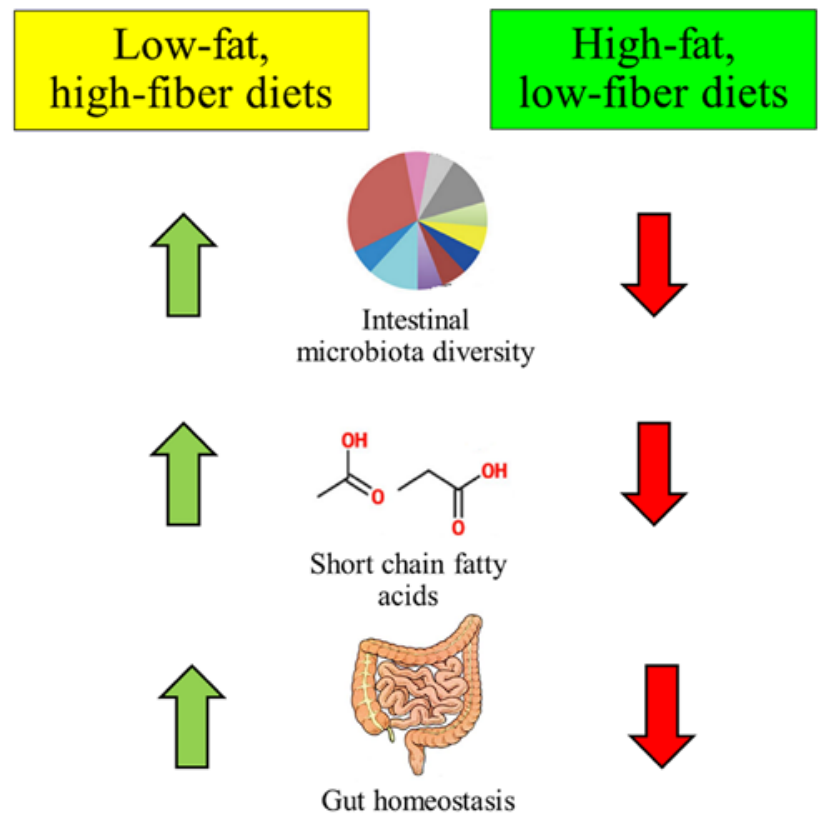

Figure 1. The effects of diets on the gut. High-fat diets affect the composition of microbiota, leading to the alteration of SCFA production in the gut, which influences intestinal homeostasis.

food consumption (98). Furthermore, a large human study found that low bacterial richness showed a positive correlation with higher weight gain supporting the concept that some bacteria may be more abundant than other types in obese individuals (99). Another study also found that obesity could be transmissible because microbiota derived from discordant obese twins caused germ-free mice to become obese when they were transplanted with these microbiota (100). This study also demonstrated that diet played a major role in gut microbiota diversity because the gut of low-fat, high-fiber diet-fed obese mice was finally dominated by the lean microbiota, which prevented increased adiposity, even when the mice were cohoused with mice with obese microbiota, suggesting that diet is responsible for the development of this phenotype (100).

\section{Colonic carcinogenesis may be promoted by diet-related carcinogenic metabolites}

CRC is a common, worldwide cancer causing up to 690,000 deaths/year (101). Although the exact etiology of CRC remains unknown, gradual accumulation of genetic mutations are essential for CRC tumorigenesis (102).

It is clear that the incidence of CRC is higher in developed countries, but in recent years, it has also become a public health problem in developing countries due to economic growth and an increasingly westernized lifestyle, including high consumption of red meats and high-calorie diets, which are associated with an increased incidence of CRC $(103,104)$. This dietary pattern of higher consumption of animal protein (Western diet) that is related to the epidemiology of CRC demonstrates the role of diet in CRC development.

The composition and activity of the intestinal microbiota can be influenced by diet (105), and there is considerable evidence linking diet-induced microbiota dysbiosis to CRC tumorigenesis (106) (Fig. 2). This relationship may be mediated by metabolites and inflammatory induction, which induce genetic mutations and inhibit apoptosis or stimulate angiogenesis and cell proliferation (107). One study found that the increased consumption of red meat was associated with higher levels of sulfur, nitrates, ammonia, amines, branched-chain amino acids, and $\mathrm{H}_{2} \mathrm{~S}$ in the colon (108), which all have been shown to be pro-inflammatory and genotoxic, that in turn facilitates colon tumorigenesis by causing DNA damage and inhibiting the oxidation of butyrate $(109,110)$. Moreover, several species of Bacteroides and some Firmicutes have shown the ability to ferment aromatic amino acids, leading to the production of toxic compounds, such as phenylacetic acid, phenols, indoles, and p-cresol, that promote colon carcinogenesis by DNA alkylation and mutations (111).

Lipid metabolism byproducts, such as bile acids, appear to be associated with the development of CRCs. Secondary bile acids, such as deoxycholic acid (DCA), are involved in the higher levels of reactive oxygen species (ROS), DNA damage, genomic instability and tumor growth $(112,113)$. Moreover, an increased risk of CRC via the higher secondary bile acid production and ROS has been found in individuals consuming a high-fat, low-fiber diet who have a higher composition of inflammatory $7 \alpha$-dehydroxylating bacteria and sulfur-reducing bacteria, which produce $\mathrm{H}_{2} \mathrm{~S}$ and secondary bile acids, respectively (109). Nitric oxide is another compound produced by specific types of bacteria. Its secondary reactive species can activate inflammation and damage DNA. An investigation by Sobko et al demonstrated that nitrite and nitrate-supplemented diets are sources for nitric oxide production by Lactobacilli and Bifidobacteria, leading to colonic mucosal inflammation and DNA damage $(114,115)$.

The barrier dysfunction mediated by microbial products during $\mathrm{CRC}$ development also leads to adenoma invasion by stimulating inflammatory cytokines, such as IL-17 and IL-23, which, in turn, support tumor growth (116). The colonic inflammation model has also demonstrated the loss of the mucosal barrier in dextran sulfate sodium (DSS)-induced 


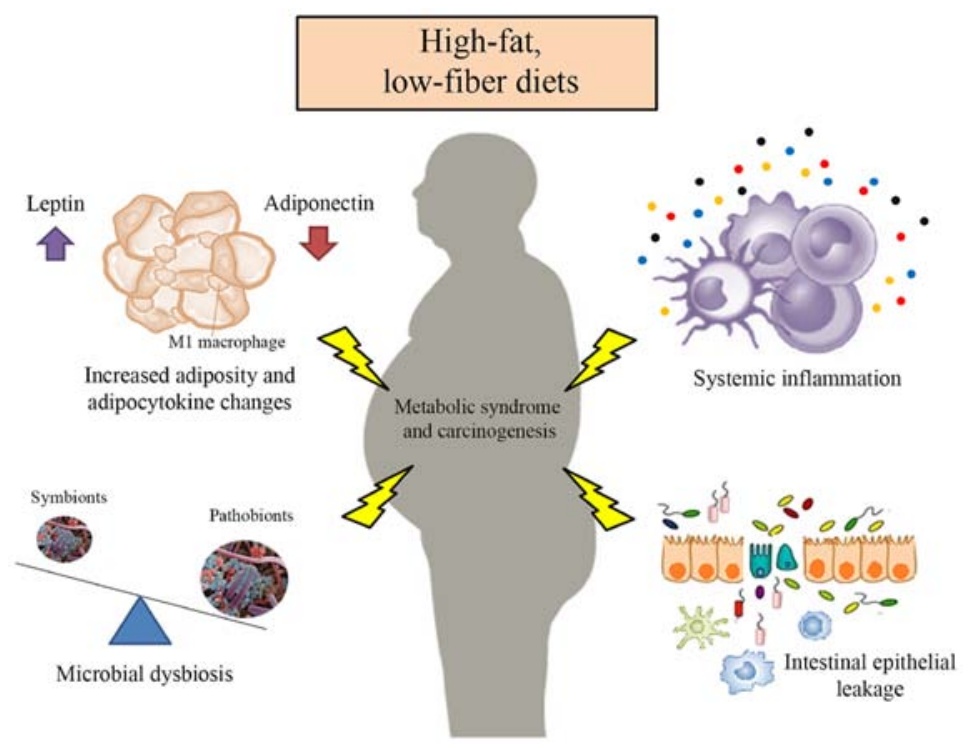

Figure 2. High-fat diets promote metabolic syndrome and colon carcinogenesis via increased adiposity, dysbiosis, gut barrier dysfunction and systemic inflammation.

colitis. However, when feeding rats with cheese whey protein, colitis markers were reduced, and fecal mucin, a family of glycosylated proteins that play a role in the intestinal mucus layer, and fecal Lactobacilli and Bifidobacteria counts were then increased (117).

\section{Adipocytokines link metabolic syndrome to the risk of CRC}

Numerous growth factors, hormones and cytokines, known as adipocytokines, can be secreted by adipose tissue and have pleiotropic effects, including regulation of food intake and metabolism, crosstalk with insulin signaling and inflammatory pathways, and promotion of angiogenesis and cellular proliferation $(118,119)$. These adipocytokines include leptin, resistin, adiponectin and various cytokines, such as TNF- $\alpha$ and IL-6. In obese patients, the levels of these adipocytokines are altered, further contributing to an increased risk of CRC $(120,121)$ (Fig. 2).

Adiponectin. Adiponectin, also known as Acrp30, ADIPOQ, apM1 or GBP28, is a $30 \mathrm{kDa}$ protein that shares homologies with complement factors and TNF- $\alpha$, and is predominantly secreted by adipocytes (122-124). This protein stimulates insulin secretion, increases fatty acid metabolism, activates energy consumption, and is also believed to have an anti-inflammatory role $(124,125)$. The results from epidemiological and preclinical studies have indicated a protective role of adiponectin against tumorigenesis because the levels of adiponectin were negatively correlated with the risk of CRC development $(126,127)$. Recent meta-analyses have shown that, in men, a $1 \mu \mathrm{g} / \mathrm{ml}$ increase in adiponectin levels was associated with a $2 \%$ reduced risk of CRC (128-130). Studies in animal models have also shown that adiponectin is involved in the suppression of colon carcinogenesis. High-fat diet-fed mice had significantly more polyps when the adiponectin gene was suppressed (131). Moreover, in vitro experiment showed that the growth of CRC cells can be inhibited by adiponectin through the activation of adenosine monophosphate-activated protein kinase (AMPK) and suppression of mammalian target of rapamycin (mTOR) pathways (132). As anti-angiogenic function, neovascularization suppression can be found in adiponectin-treated mice fed a high-fat diet, resulting in significant inhibition of CRC cell growth (133). Adiponectin also showed immunoregulatory functions because this protein induces macrophage infiltration in tumor area (134).

Leptin. Leptin is an adipocyte-derived $O b$ gene product that plays a major role in the modulation of appetite and energy homeostasis. This is through the feedback regulation between the central nervous system and the peripheral adipose tissue $(135,136)$. Leptin levels appear to be positively associated with obesity and CRC $(137,138)$, and they are believed to be an important factor in the intercellular interactions between adipocytes, fibroblasts, epithelial cells and immune cells (139). An investigation of 108 CRC patients indicated a relationship between leptin levels and progression of cancer, such as lymph node metastasis, distant metastasis and differentiation, suggesting that leptin is involved in cancer proliferation and apoptosis, which may be through the PI3K/Akt/mTOR signaling pathway (140). Leptin also has an anti-apoptotic role in human colon cancer cell lines and promotes the proliferation of normal colonic epithelial and cancer cells as the Wnt signaling pathway, a key pathway in CRC, can be activated by leptin, leading to CRC cell proliferation in vitro (141), while leptin-deficient mice showed a dramatic inhibition of tumor growth (142). Moreover, leptin can also promote CRC progression by stimulating VEGF secretion through hypoxia-inducible factor-1 (HIF-1) and nuclear factor- $\mathrm{\kappa B}(\mathrm{NF}-\mathrm{\kappa} \mathrm{B})$ activation $(17,143)$. Interestingly, it is clear that leptin and adiponectin can neutralize each other's proliferative function because leptin plays a role in blocking the anti-proliferative effects of adiponectin in cancer cells (144), while adiponectin has a negative effect on the proliferative function of leptin (145). This suggests that the cancer risk related to metabolic syndrome can be accurately assessed by the leptin-to-adiponectin ratio. 
TNF- $\alpha$. TNF- $\alpha$ levels in systemic and adipose tissue are higher in obese individuals than in lean subjects (145). Although this cytokine has a functional role in apoptosis, cell necrosis, tumorigenesis inhibition, and appetite reduction (143), its pro-inflammatory role now has been associated with all steps of tumorigenesis (145). High levels of TNF- $\alpha$ in the colonic mucosa of high-fat diet mice resulted in $\beta$-catenin activation, leading to increased transcription of $c-M y c$, a downstream molecule in the Wnt signaling pathway (146). Moreover, this pro-inflammatory cytokine can activate NF- $\kappa B$, a transcription factor associated with cell proliferation, apoptosis inhibition, tissue invasion, angiogenesis and metastasis, implying that this stimulation is involved in the progression of carcinogenesis $(147,148)$.

Insulin and insulin-like growth factors (IGFs). Although insulin and IGFs are produced by $\beta$-cells in the pancreas and liver, respectively, not in adipose tissue, these factors still play a role in CRC cell proliferation and the progression of cancer both in vitro and in vivo. Circulating total IGF-1 has been positively associated with obesity and thus also contributes to an increased CRC risk (149); one study showed that IGF receptors were found in CRC cells (150). Importantly, several investigations have demonstrated that by binding to these receptors, insulin stimulates proliferation of cultured colonocytes and CRC cells directly, leading to the activation of the MAPK pathway $(151,152)$. This scenario was supported in a study that used monoclonal antibodies against IGF1 and found inhibition of CRC stem cells in mice (153).

\section{Conclusion}

Over the last centuries, diets have been shown to affect the pathophysiological development of metabolic syndrome and CRC. Although the precise mechanisms have not been clearly elucidated, it is believed that intestinal inflammation and alteration of adipokines, which may result from a high-fat, low-fiber diet, plays a key role in these processes. This type of diet influences the metabolic activity of the gut and changes the composition of the microbiota, resulting in inflammation and carcinogenesis. Importantly, further investigations are needed for a deeper understanding of the effect of these abnormalities on metabolic imbalance and CRC development. This may lead to the development of new strategies that improve or even treat metabolic syndrome and CRC.

\section{References}

1. Balkau B, Deanfield JE, Després JP, Bassand JP, Fox KA, Smith SC Jr, Barter P, Tan CE, Van Gaal L, Wittchen HU, et al International Day for the Evaluation of Abdominal Obesity (IDEA): a study of waist circumference, cardiovascular disease, and diabetes mellitus in 168,000 primary care patients in 63 countries. Circulation 116: 1942-1951, 2007

2. Grundy SM: Metabolic syndrome pandemic. Arterioscler Thromb Vasc Biol 28: 629-636, 2008

3. Prasad DS, Kabir Z, Dash AK and Das BC: Prevalence and risk factors for metabolic syndrome in Asian Indians: a community study from urban Eastern India. J Cardiovasc Dis Res 3: 204-211, 2012.

4. Gu D, Reynolds K, Wu X, Chen J, Duan X, Reynolds RF, Whelton PK and He J; InterASIA Collaborative Group: Prevalence of the metabolic syndrome and overweight among adults in China. Lancet 365: 1398-1405, 2005.

5. Reynolds $\mathrm{K}$ and $\mathrm{He} \mathrm{J}$ : Epidemiology of the metabolic syndrome. Am J Med Sci 330: 273-279, 2005.
6. Wilson PW: Metabolic risk factors for coronary heart disease: current and future prospects. Curr Opin Cardiol 14: 176-185, 1999.

7. Miranda PJ, DeFronzo RA, Califf RM and Guyton JR: Metabolic syndrome: definition, pathophysiology, and mechanisms. Am Heart J 149: 33-45, 2005.

8. Dentali F, di Minno MN, Gianni M, di Minno G, Squizzato A and Ageno W: The role of the metabolic syndrome in patients with provoked venous thromboembolic events. Thromb Haemost 109: 759-761, 2013.

9. van Rooy MJ, Duim W, Ehlers R, Buys AV and Pretorius E: Platelet hyperactivity and fibrin clot structure in transient ischemic attack individuals in the presence of metabolic syndrome: a microscopy and thromboelastography study. Cardiovasc Diabetol 14: 86, 2015.

10. Ebrahimi $\mathrm{F}$ and Christ-Crain $\mathrm{M}$ : Metabolic syndrome and hypogonadism - two peas in a pod. Swiss Med Wkly 146: w14283, 2016.

11. Uzunlulu M, Telci Caklili $\mathrm{O}$ and Oguz A: Association between metabolic syndrome and cancer. Ann Nutr Metab 68: 173-179, 2016.

12. Chen J, He X and Huang J: Diet effects in gut microbiome and obesity. J Food Sci 79: R442-R451, 2014.

13. Festi D, Schiumerini R, Eusebi LH, Marasco G, Taddia M and Colecchia A: Gut microbiota and metabolic syndrome. World J Gastroenterol 20: 16079-16094, 2014.

14. Parekh PJ, Balart LA and Johnson DA: The Influence of the gut microbiome on obesity, metabolic syndrome and gastrointestinal disease. Clin Transl Gastroenterol 6: e91, 2015.

15. Marchesi JR, Adams DH, Fava F, Hermes GD, Hirschfield GM, Hold G, Quraishi MN, Kinross J, Smidt H, Tuohy KM, et al: The gut microbiota and host health: a new clinical frontier. Gut 65: 330-339, 2016.

16. Pigrau M, Rodiño-Janeiro BK, Casado-Bedmar M, Lobo B, Vicario M, Santos J and Alonso-Cotoner C: The joint power of sex and stress to modulate brain-gut-microbiota axis and intestinal barrier homeostasis: implications for irritable bowel syndrome. Neurogastroenterol Motil 28: 463-486, 2016.

17. Aballay LR, Eynard AR, Díaz M del P, Navarro A and Muñoz SE: Overweight and obesity: a review of their relationship to metabolic syndrome, cardiovascular disease, and cancer in South America. Nutr Rev 71: 168-179, 2013.

18. Welty FK, Alfaddagh A and Elajami TK: Targeting inflammation in metabolic syndrome. Transl Res 167: 257-280, 2016.

19. Ley RE, Bäckhed F, Turnbaugh P, Lozupone CA, Knight RD and Gordon JI: Obesity alters gut microbial ecology. Proc Natl Acad Sci USA 102: 11070-11075, 2005.

20. Pischon T, Lahmann PH, Boeing H, Friedenreich C, Norat $T$, Tjønneland A, Halkjaer J, Overvad K, Clavel-Chapelon F, Boutron-Ruault MC, et al: Body size and risk of colon and rectal cancer in the European Prospective Investigation Into Cancer and Nutrition (EPIC). J Natl Cancer Inst 98: 920-931, 2006.

21. Pelucchi C, Negri E, Talamini R, Levi F, Giacosa A, Crispo A, Bidoli E, Montella M, Franceschi S and La Vecchia C: Metabolic syndrome is associated with colorectal cancer in men. Eur J Cancer 46: 1866-1872, 2010.

22. Esposito K, Chiodini P, Colao A, Lenzi A and Giugliano D: Metabolic syndrome and risk of cancer: a systematic review and meta-analysis. Diabetes Care 35: 2402-2411, 2012.

23. Kyrou I, Randeva HS and Weickert MO: Clinical problems caused by obesity: Endotext (Internet). De Groot LJ, Chrousos G, Dungan K, Feingold KR, Grossman A, Hershman JM, Koch C, Korbonits M, McLachlan R, New M, et al (eds). MDText.com, Inc., South Dartmouth, MA, USA, 2000. www.endotext.org. Accessed April 24, 2014.

24. Knecht S, Ellger T and Levine JA: Obesity in neurobiology. Prog Neurobiol 84: 85-103, 2008.

25. Sheth RD: Metabolic concerns associated with antiepileptic medications. Neurology 63 (Suppl 4): S24-S29, 2004.

26. Broberger C: Brain regulation of food intake and appetite: molecules and networks. J Intern Med 258: 301-327, 2005.

27. Peters A, Schweiger U, Pellerin L, Hubold C, Oltmanns KM, Conrad M, Schultes B, Born J and Fehm HL: The selfish brain: competition for energy resources. Neurosci Biobehav Rev 28: 143-180, 2004.

28. Peters A, Pellerin L, Dallman MF, Oltmanns KM, Schweiger U, Born J and Fehm HL: Causes of obesity: looking beyond the hypothalamus. Prog Neurobiol 81: 61-88, 2007.

29. Woods SC, Stein LJ, McKay LD and Porte D Jr: Suppression of food intake by intravenous nutrients and insulin in the baboon. Am J Physiol 247: R393-R401, 1984. 
30. Ahima RS, Prabakaran D, Mantzoros C, Qu D, Lowell B, Maratos-Flier E and Flier JS: Role of leptin in the neuroendocrine response to fasting. Nature 382: 250-252, 1996.

31. Kreier F, Kap YS, Mettenleiter TC, van Heijningen C, van der Vliet J, Kalsbeek A, Sauerwein HP, Fliers E, Romijn JA and Buijs RM: Tracing from fat tissue, liver, and pancreas: a neuroanatomical framework for the role of the brain in type 2 diabetes. Endocrinology 147: 1140-1147, 2006.

32. Uno K, Katagiri H, Yamada T, Ishigaki Y, Ogihara T, Imai J, Hasegawa Y, Gao J, Kaneko K, Iwasaki H, et al: Neuronal pathway from the liver modulates energy expenditure and systemic insulin sensitivity. Science 312: 1656-1659, 2006.

33. Dhillon H, Zigman JM, Ye C, Lee CE, McGovern RA, Tang V, Kenny CD, Christiansen LM, White RD, Edelstein EA, et al: Leptin directly activates SF1 neurons in the VMH, and this action by leptin is required for normal body-weight homeostasis. Neuron 49: 191-203, 2006.

34. Brown FD, Fessler RG, Rachlin JR and Mullan S: Changes in food intake with electrical stimulation of the ventromedial hypothalamus in dogs. J Neurosurg 60: 1253-1257, 1984.

35. Choi S, Sparks R, Clay M and Dallman MF: Rats with hypothalamic obesity are insensitive to central leptin injections. Endocrinology 140: 4426-4433, 1999.

36. Grundmann SJ, Pankey EA, Cook MM, Wood AL, Rollins BL and King BM: Combination unilateral amygdaloid and ventromedial hypothalamic lesions: evidence for a feeding pathway. Am J Physiol Regul Integr Comp Physiol 288: R702-R707, 2005.

37. Majdic G, Young M, Gomez-Sanchez E, Anderson P, Szczepaniak LS, Dobbins RL, McGarry JD and Parker KL: Knockout mice lacking steroidogenic factor 1 are a novel genetic model of hypothalamic obesity. Endocrinology 143 607-614, 2002.

38. Bingham NC, Anderson KK, Reuter AL, Stallings NR and Parker KL: Selective loss of leptin receptors in the ventromedial hypothalamic nucleus results in increased adiposity and a metabolic syndrome. Endocrinology 149: 2138-2148, 2008.

39. Coleman DL: Obese and diabetes: two mutant genes causing diabetes-obesity syndromes in mice. Diabetologia 14: 141-148, 1978

40. Clément K, Vaisse C, Lahlou N, Cabrol S, Pelloux V, Cassuto D, Gourmelen M, Dina C, Chambaz J, Lacorte JM, et al: A mutation in the human leptin receptor gene causes obesity and pituitary dysfunction. Nature 392: 398-401, 1998.

41. Montague CT, Farooqi IS, Whitehead JP, Soos MA, Rau H, Wareham NJ, Sewter CP, Digby JE, Mohammed SN, Hurst JA, et al: Congenital leptin deficiency is associated with severe early-onset obesity in humans. Nature 387: 903-908, 1997.

42. Kaszubska W, Falls HD, Schaefer VG, Haasch D, Frost L, Hessler P, Kroeger PE, White DW, Jirousek MR and Trevillyan JM: Protein tyrosine phosphatase 1B negatively regulates leptin signaling in a hypothalamic cell line. Mol Cell Endocrinol 195: 109-118, 2002.

43. Egawa K, Maegawa H, Shimizu S, Morino K, Nishio Y, Bryer-Ash M, Cheung AT, Kolls JK, Kikkawa R and Kashiwagi A: Protein-tyrosine phosphatase-1B negatively regulates insulin signaling in 16 myocytes and Fao hepatoma cells. J Biol Chem 276: 10207-10211, 2001.

44. Bence KK, Delibegovic M, Xue B, Gorgun CZ, Hotamisligil GS, Neel BG and Kahn BB: Neuronal PTP1B regulates body weight, adiposity and leptin action. Nat Med 12: 917-924, 2006.

45. Cox JE and Powley TL: Prior vagotomy blocks VMH obesity in pair-fed rats. Am J Physiol 240: E573-E583, 1981.

46. Brüning JC, Gautam D, Burks DJ, Gillette J, Schubert M, Orban PC, Klein R, Krone W, Müller-Wieland D and Kahn CR: Role of brain insulin receptor in control of body weight and reproduction. Science 289: 2122-2125, 2000.

47. Volkow ND and Wise RA: How can drug addiction help us understand obesity? Nat Neurosci 8: 555-560, 2005.

48. Wallenius V, Wallenius K, Ahrén B, Rudling M, Carlsten H, Dickson SL, Ohlsson C and Jansson JO: Interleukin-6-deficient mice develop mature-onset obesity. Nat Med 8: 75-79, 2002.

49. King BM: Amygdaloid lesion-induced obesity: relation to sexual behavior, olfaction, and the ventromedial hypothalamus. Am J Physiol Regul Integr Comp Physiol 291: R1201-R1214, 2006.

50. Peters A: The selfish brain: competition for energy resources. Am J Hum Biol 23: 29-34, 2011.

51. Peters A and McEwen BS: Stress habituation, body shape and cardiovascular mortality. Neurosci Biobehav Rev 56: 139-150, 2015.

52. Hitze B, Hubold C, van Dyken R, Schlichting K, Lehnert H, Entringer S and Peters A: How the selfish brain organizes its supply and demand. Front Neuroenergetics 2: 7, 2010.
53. Kubera B, Hubold C, Zug S, Wischnath H, Wilhelm I, Hallschmid M, Entringer S, Langemann D and Peters A: The brain's supply and demand in obesity. Front Neuroenergetics 4: 4, 2012.

54. Khodabandehloo H, Gorgani-Firuzjaee S, Panahi G and Meshkani R: Molecular and cellular mechanisms linking inflammation to insulin resistance and $\beta$-cell dysfunction. Transl Res 167: 228-256, 2016.

55. Cai D and Liu T: Hypothalamic inflammation: a double-edged sword to nutritional diseases. Ann N Y Acad Sci 1243: E1-E39, 2011

56. Cai D and Liu T: Inflammatory cause of metabolic syndrome

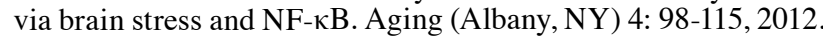

57. Gregor MF and Hotamisligil GS: Inflammatory mechanisms in obesity. Annu Rev Immunol 29: 415-445, 2011

58. Weisberg SP, McCann D, Desai M, Rosenbaum M, Leibel RL and Ferrante AW Jr: Obesity is associated with macrophage accumulation in adipose tissue. J Clin Invest 112: 1796-1808, 2003.

59. Lee BC and Lee J: Cellular and molecular players in adipose tissue inflammation in the development of obesity-induced insulin resistance. Biochim Biophys Acta 1842: 446-462, 2014.

60. Lynch L, Nowak M, Varghese B, Clark J, Hogan AE, Toxavidis V, Balk SP, O'Shea D, O'Farrelly C and Exley MA: Adipose tissue invariant NKT cells protect against diet-induced obesity and metabolic disorder through regulatory cytokine production. Immunity 37: 574-587, 2012.

61. Yoshimura A, Ohnishi S, Orito C, Kawahara Y, Takasaki H, Takeda H, Sakamoto N and Hashino S: Association of peripheral total and differential leukocyte counts with obesity-related complications in young adults. Obes Facts 8: 1-16, 2015.

62. Krinninger P, Ensenauer R, Ehlers K, Rauh K, Stoll J, Krauss-Etschmann S, Hauner $\mathrm{H}$ and Laumen H: Peripheral monocytes of obese women display increased chemokine receptor expression and migration capacity. J Clin Endocrinol Metab 99: 2500-2509, 2014.

63. Poitou C, Dalmas E, Renovato M, Benhamo V, Hajduch F, Abdennour M, Kahn JF, Veyrie N, Rizkalla S, Fridman WH, et al: $\mathrm{CD} 14^{\mathrm{dim}} \mathrm{CD} 16^{+}$and $\mathrm{CD} 14^{+} \mathrm{CD} 16^{+}$monocytes in obesity and during weight loss: relationships with fat mass and subclinical atherosclerosis. Arterioscler Thromb Vasc Biol 31: 2322-2330, 2011.

64. Christiansen T, Richelsen B and Bruun JM: Monocyte chemoattractant protein-1 is produced in isolated adipocytes, associated with adiposity and reduced after weight loss in morbid obese subjects. Int J Obes 29: 146-150, 2005.

65. Kanda H, Tateya S, Tamori Y, Kotani K, Hiasa K, Kitazawa R, Kitazawa S, Miyachi H, Maeda S, Egashira K, et al: MCP-1 contributes to macrophage infiltration into adipose tissue, insulin resistance, and hepatic steatosis in obesity. J Clin Invest 116: 1494-1505, 2006.

66. Weisberg SP, Hunter D, Huber R, Lemieux J, Slaymaker S, Vaddi K, Charo I, Leibel RL and Ferrante AW Jr: CCR2 modulates inflammatory and metabolic effects of high-fat feeding. J Clin Invest 116: 115-124, 2006.

67. Bolus WR, Gutierrez DA, Kennedy AJ, Anderson-Baucum EK and Hasty AH: CCR2 deficiency leads to increased eosinophils, alternative macrophage activation, and type 2 cytokine expression in adipose tissue. J Leukoc Biol 98: 467-477, 2015.

68. Kim D, Kim J, Yoon JH, Ghim J, Yea K, Song P, Park S, Lee A, Hong CP, Jang MS, et al: CXCL12 secreted from adipose tissue recruits macrophages and induces insulin resistance in mice. Diabetologia 57: 1456-1465, 2014.

69. Nara N, Nakayama Y, Okamoto S, Tamura H, Kiyono M, Muraoka M, Tanaka K, Taya C, Shitara H, Ishii R, et al: Disruption of CXC motif chemokine ligand-14 in mice ameliorates obesity-induced insulin resistance. J Biol Chem 282: 30794-30803, 2007.

70. Kitade H, Sawamoto $K$, Nagashimada $M$, Inoue $H$, Yamamoto Y, Sai Y, Takamura T, Yamamoto H, Miyamoto K, Ginsberg HN, et al: CCR5 plays a critical role in obesity-induced adipose tissue inflammation and insulin resistance by regulating both macrophage recruitment and M1/M2 status. Diabetes 61: 1680-1690, 2012.

71. Dalmas E,Clément K and Guerre-Millo M: Defining macrophage phenotype and function in adipose tissue. Trends Immunol 32: 307-314, 2011.

72. Lumeng CN, Bodzin JL and Saltiel AR: Obesity induces a phenotypic switch in adipose tissue macrophage polarization. $\mathrm{J}$ Clin Invest 117: 175-184, 2007. 
73. Kratz M, Coats BR, Hisert KB, Hagman D, Mutskov V, Peris E, Schoenfelt KQ, Kuzma JN, Larson I, Billing PS, et al: Metabolic dysfunction drives a mechanistically distinct proinflammatory phenotype in adipose tissue macrophages. Cell Metab 20: 614-625, 2014.

74. Elgazar-Carmon V, Rudich A, Hadad N and Levy R: Neutrophils transiently infiltrate intra-abdominal fat early in the course of high-fat feeding. J Lipid Res 49: 1894-1903, 2008.

75. Talukdar S, Oh DY, Bandyopadhyay G, Li D, Xu J, McNelis J, Lu M, Li P, Yan Q, Zhu Y, et al: Neutrophils mediate insulin resistance in mice fed a high-fat diet through secreted elastase. Nat Med 18: 1407-1412, 2012.

76. Xu X, Su S, Wang X, Barnes V, De Miguel C, Ownby D, Pollock J, Snieder H, Chen W and Wang X: Obesity is associated with more activated neutrophils in African American male youth. Int J Obes (Lond) 39: 26-32, 2015.

77. Sell H, Habich C and Eckel J: Adaptive immunity in obesity and insulin resistance. Nat Rev Endocrinol 8: 709-716, 2012.

78. Feuerer M, Herrero L, Cipolletta D, Naaz A, Wong J, Nayer A, Lee J, Goldfine AB, Benoist C, Shoelson S, et al: Lean, but not obese, fat is enriched for a unique population of regulatory $\mathrm{T}$ cells that affect metabolic parameters. Nat Med 15: 930-939, 2009.

79. Strissel KJ, DeFuria J, Shaul ME, Bennett G, Greenberg AS and Obin MS: T-cell recruitment and Th1 polarization in adipose tissue during diet-induced obesity in C57BL/6 mice. Obesity (Silver Spring) 18: 1918-1925, 2010.

80. Winer S, Paltser G, Chan Y, Tsui H, Engleman E, Winer D and Dosch HM: Obesity predisposes to Th17 bias. Eur J Immunol 39: 2629-2635, 2009.

81. Nishimura S, Manabe I, Nagasaki M, Eto K, Yamashita H, Ohsugi M, Otsu M, Hara K, Ueki K, Sugiura S, et al: CD8 effector $\mathrm{T}$ cells contribute to macrophage recruitment and adipose tissue inflammation in obesity. Nat Med 15: 914-920, 2009.

82. Wu H, Ghosh S, Perrard XD, Feng L, Garcia GE, Perrard JL Sweeney JF, Peterson LE, Chan L, Smith CW, et al: T-cell accumulation and regulated on activation, normal $\mathrm{T}$ cell expressed and secreted upregulation in adipose tissue in obesity. Circulation 115: 1029-1038, 2007.

83. Winer DA, Winer S, Shen L, Wadia PP, Yantha J, Paltser G, Tsui H, Wu P, Davidson MG, Alonso MN, et al: B cells promote insulin resistance through modulation of $\mathrm{T}$ cells and production of pathogenic IgG antibodies. Nat Med 17: 610-617, 2011.

84. Sun S, Ji Y, Kersten S and Qi L: Mechanisms of inflammatory responses in obese adipose tissue. Annu Rev Nutr 32 261-286, 2012

85. Duffaut C, Galitzky J, Lafontan M and Bouloumié A: Unexpected trafficking of immune cells within the adipose tissue during the onset of obesity. Biochem Biophys Res Commun 384 482-485, 2009

86. DeFuria J, Belkina AC, Jagannathan-Bogdan M, SnyderCappione J, Carr JD, Nersesova YR, Markham D, Strissel KJ, Watkins AA, Zhu M, et al: B cells promote inflammation in obesity and type 2 diabetes through regulation of T-cell function and an inflammatory cytokine profile. Proc Natl Acad Sci USA 110: 5133-5138, 2013

87. Jagannathan M, McDonnell M, Liang Y, Hasturk H, Hetzel J, Rubin D, Kantarci A, Van Dyke TE, Ganley-Leal LM and Nikolajczyk BS: Toll-like receptors regulate B cell cytokine production in patients with diabetes. Diabetologia 53 $1461-1471,2010$

88. van Exel E, Gussekloo J, de Craen AJM, Frölich M, Bootsma-Van Der Wiel A and Westendorp RGJ; Leiden 85 Plus Study: Low production capacity of interleukin-10 associates with the metabolic syndrome and type 2 diabetes: The Leiden 85-Plus Study. Diabetes 51: 1088-1092, 2002.

89. Gomes AC, Bueno AA, de Souza RGM and Mota JF: Gut microbiota, probiotics and diabetes. Nutr J 13: 60, 2014

90. Bajzer M and Seeley RJ: Physiology: obesity and gut flora. Nature 444: 1009-1010, 2006.

91. Sekirov I, Russell SL, Antunes LCM and Finlay BB: Gut microbiota in health and disease. Physiol Rev 90: 859-904, 2010

92. David LA, Maurice CF, Carmody RN, Gootenberg DB, Button JE, Wolfe BE, Ling AV, Devlin AS, Varma Y, Fischbach MA, et al: Diet rapidly and reproducibly alters the human gut microbiome. Nature 505: 559-563, 2014.

93. Turnbaugh PJ, Hamady M, Yatsunenko T, Cantarel BL, Duncan A Ley RE, Sogin ML, Jones WJ, Roe BA, Affourtit JP, et al: A core gut microbiome in obese and lean twins. Nature 457: 480-484, 2009
94. Trompette A, Gollwitzer ES, Yadava K, Sichelstiel AK, Sprenger N, Ngom-Bru C, Blanchard C, Junt T, Nicod LP, Harris NL, et al: Gut microbiota metabolism of dietary fiber influences allergic airway disease and hematopoiesis. Nat Med 20: 159-166, 2014

95.Ley RE, Turnbaugh PJ, Klein S and Gordon JI: Microbial ecology: human gut microbes associated with obesity. Nature 444: 1022-1023, 2006.

96. Schwiertz A, Taras D, Schäfer K, Beijer S, Bos NA, Donus C and Hardt PD: Microbiota and SCFA in lean and overweight healthy subjects. Obesity (Silver Spring) 18: 190-195, 2010.

97. Duncan SH, Lobley GE, Holtrop G, Ince J, Johnstone AM, Louis $\mathrm{P}$ and Flint HJ: Human colonic microbiota associated with diet, obesity and weight loss. Int J Obes 32: 1720-1724, 2008

98. Bäckhed F, Ding H, Wang T, Hooper LV, Koh GY, Nagy A, Semenkovich CF and Gordon JI: The gut microbiota as an environmental factor that regulates fat storage. Proc Natl Acad Sci USA 101: 15718-15723, 2004.

99. Le Chatelier E, Nielsen T, Qin J, Prifti E, Hildebrand F, Falony G, Almeida M, Arumugam M, Batto JM, Kennedy S, et al; MetaHIT consortium: Richness of human gut microbiome correlates with metabolic markers. Nature 500: 541-546, 2013.

100. Ridaura VK, Faith JJ, Rey FE, Cheng J, Duncan AE, Kau AL, Griffin NW, Lombard V, Henrissat B, Bain JR, et al: Gut microbiota from twins discordant for obesity modulate metabolism in mice. Science 341: 1241214, 2013.

101. Ferlay J, Soerjomataram I, Dikshit R, Eser S, Mathers C, Rebelo M, Parkin DM, Forman D and Bray F: Cancer incidence and mortality worldwide: sources, methods and major patterns in GLOBOCAN 2012. Int J Cancer 136: E359-E386, 2015.

102. Sears CL and Garrett WS: Microbes, microbiota, and colon cancer. Cell Host Microbe 15: 317-328, 2014

103. Center MM, Jemal A and Ward E: International trends in colorectal cancer incidence rates. Cancer Epidemiol Biomarkers Prev 18: 1688-1694, 2009.

104. Center MM, Jemal A, Smith RA and Ward E: Worldwide variations in colorectal cancer. CA Cancer J Clin 59: 366-378, 2009

105. Duncan SH, Belenguer A, Holtrop G, Johnstone AM, Flint HJ and Lobley GE: Reduced dietary intake of carbohydrates by obese subjects results in decreased concentrations of butyrate and butyrate-producing bacteria in feces. Appl Environ Microbiol 73: 1073-1078, 2007.

106.Keku TO, Dulal S, Deveaux A, Jovov B and Han X: The gastrointestinal microbiota and colorectal cancer. Am J Physiol Gastrointest Liver Physiol 308: G351-G363, 2015.

107. Medzhitov R: Origin and physiological roles of inflammation. Nature 454: 428-435, 2008

108. Nyangale EP, Mottram DS and Gibson GR: Gut microbial activity, implications for health and disease: the potential role of metabolite analysis. J Proteome Res 11: 5573-5585, 2012.

109. Greer JB and O'Keefe SJ: Microbial induction of immunity, inflammation, and cancer. Front Physiol 1: 168, 2011.

110. Módis K, Coletta C, Erdélyi K, Papapetropoulos A and Szabo C: Intramitochondrial hydrogen sulfide production by 3-mercaptopyruvate sulfurtransferase maintains mitochondrial electron flow and supports cellular bioenergetics. FASEB J 27: 601-611, 2013

111. Nistal E, Fernández-Fernández N, Vivas S and Olcoz JL: Factors determining colorectal cancer: the role of the intestinal microbiota. Front Oncol 5: 220, 2015.

112. Dvorak K, Payne CM, Chavarria M, Ramsey L, Dvorakova B, Bernstein H, Holubec H, Sampliner RE, Guy N, Condon A, et al: Bile acids in combination with low $\mathrm{pH}$ induce oxidative stress and oxidative DNA damage: relevance to the pathogenesis of Barrett's oesophagus. Gut 56: 763-771, 2007.

113. Gill CI and Rowland IR: Diet and cancer: assessing the risk. $\mathrm{Br}$ J Nutr 88 (Suppl 1): S73-S87, 2002.

114. Sobko T, Huang L, Midtvedt T, Norin E, Gustafsson LE, Norman M, Jansson EA and Lundberg JO: Generation of NO by probiotic bacteria in the gastrointestinal tract. Free Radic Biol Med 41: 985-991, 2006

115. Sobko T, Reinders CI, Jansson E, Norin E, Midtvedt T and Lundberg JO: Gastrointestinal bacteria generate nitric oxide from nitrate and nitrite. Nitric Oxide 13: 272-278, 2005.

116. Grivennikov SI, Wang K, Mucida D, Stewart CA, Schnabl B, Jauch D, Taniguchi K, Yu GY, Osterreicher CH, Hung KE, et al: Adenoma-linked barrier defects and microbial products drive IL-23/IL-17-mediated tumour growth. Nature 491: $254-258,2012$ 
117. Sprong RC, Schonewille AJ and van der Meer R: Dietary cheese whey protein protects rats against mild dextran sulfate sodium-induced colitis: role of mucin and microbiota. J Dairy Sci 93: 1364-1371, 2010.

118. Hursting SD, Digiovanni J, Dannenberg AJ, Azrad M, Leroith D, Demark-Wahnefried W, Kakarala M, Brodie A and Berger NA: Obesity, energy balance, and cancer: new opportunities for prevention. Cancer Prev Res (Phila) 5: 1260-1272, 2012.

119. Tilg H and Moschen AR: Adipocytokines: mediators linking adipose tissue, inflammation and immunity. Nat Rev Immunol 6: 772-783, 2006.

120. Bardou M, Barkun AN and Martel M: Obesity and colorectal cancer. Gut 62: 933-947, 2013.

121. Barb D, Williams CJ, Neuwirth AK and Mantzoros CS Adiponectin in relation to malignancies: a review of existing basic research and clinical evidence. Am J Clin Nutr 86: s858-s866, 2007.

122. Scherer PE, Williams S, Fogliano M, Baldini G and Lodish HF: A novel serum protein similar to Clq, produced exclusively in adipocytes. J Biol Chem 270: 26746-26749, 1995.

123. Kadowaki T, Yamauchi T, Kubota N, Hara K, Ueki K and Tobe K: Adiponectin and adiponectin receptors in insulin resistance, diabetes, and the metabolic syndrome. J Clin Invest 116: 1784-1792, 2006

124. Nakashima R, Kamei N, Yamane K, Nakanishi S, Nakashima A and Kohno N: Decreased total and high molecular weight adiponectin are independent risk factors for the development of type 2 diabetes in Japanese-Americans. J Clin Endocrinol Metab 91: 3873-3877, 2006.

125. Renehan AG, Zwahlen M and Egger M: Adiposity and cancer risk: new mechanistic insights from epidemiology. Nat Rev Cancer 15: 484-498, 2015.

126.Guffey CR, Fan D, Singh UP and Murphy EA: Linking obesity to colorectal cancer: recent insights into plausible biological mechanisms. Curr Opin Clin Nutr Metab Care 16: 595-600, 2013.

127. Hillenbrand A, Fassler J, Huber N, Xu P, Henne-Bruns D, Templin M, Schrezenmeier H, Wolf AM and Knippschild U: Changed adipocytokine concentrations in colorectal tumor patients and morbidly obese patients compared to healthy controls. BMC Cancer 12: 545, 2012.

128. Xu XT, Xu Q, Tong JL, Zhu MM, Huang ML, Ran ZH and Xiao SD: Meta-analysis: circulating adiponectin levels and risk of colorectal cancer and adenoma. J Dig Dis 12: 234-244, 2011.

129. An W, Bai Y, Deng SX, Gao J, Ben QW, Cai QC, Zhang HG and Li ZS: Adiponectin levels in patients with colorectal cancer and adenoma: a meta-analysis. Eur J Cancer Prev 21: 126-133, 2012.

130. Gulcelik MA, Colakoglu K, Dincer H, Dogan L, Yenidogan E and Gulcelik NE: Associations between adiponectin and two different cancers: breast and colon. Asian Pac J Cancer Prev 13: 395-398, 2012.

131. Fujisawa T, Endo H, Tomimoto A, Sugiyama M, Takahashi H, Saito S, Inamori M, Nakajima N, Watanabe M, Kubota N, et al: Adiponectin suppresses colorectal carcinogenesis under the high-fat diet condition. Gut 57: 1531-1538, 2008.

132. Sugiyama M, Takahashi H, Hosono K, Endo H, Kato S, Yoneda K, Nozaki Y, Fujita K, Yoneda M, Wada K, et al: Adiponectin inhibits colorectal cancer cell growth through the AMPK/mTOR pathway. Int J Oncol 34: 339-344, 2009.

133. Moon HS, Liu X, Nagel JM, Chamberland JP, Diakopoulos KN, Brinkoetter MT, Hatziapostolou M, Wu Y, Robson SC, Iliopoulos D, et al: Salutary effects of adiponectin on colon cancer: in vivo and in vitro studies in mice. Gut 62: 561-570, 2013.

134. Sun Y and Lodish HF: Adiponectin deficiency promotes tumor growth in mice by reducing macrophage infiltration. PLoS One 5: e11987, 2010.
135. Vansaun MN: Molecular pathways: adiponectin and leptin signaling in cancer. Clin Cancer Res 19: 1926-1932, 2013.

136. Friedman JM and Halaas JL: Leptin and the regulation of body weight in mammals. Nature 395: 763-770, 1998.

137. Ryan AS, Berman DM, Nicklas BJ, Sinha M, Gingerich RL, Meneilly GS, Egan JM and Elahi D: Plasma adiponectin and leptin levels, body composition, and glucose utilization in adult women with wide ranges of age and obesity. Diabetes Care 26: 2383-2388, 2003

138. Tamakoshi K, Toyoshima H, Wakai K, Kojima M, Suzuki K, Watanabe Y, Hayakawa N, Yatsuya H, Kondo T, Tokudome S, et al: Leptin is associated with an increased female colorectal cancer risk: a nested case-control study in Japan. Oncology 68: 454-461, 2005.

139. Delort L, Rossary A, Farges MC, Vasson MP and Caldefie-Chézet F: Leptin, adipocytes and breast cancer: focus on inflammation and anti-tumor immunity. Life Sci 140: $37-48,2015$

140.Wang D, Chen J, Chen H, Duan Z, Xu Q, Wei M, Wang L and Zhong $\mathrm{M}$ : Leptin regulates proliferation and apoptosis of colorectal carcinoma through PI3K/Akt/mTOR signalling pathway. J Biosci 37: 91-101, 2012.

141.Padidar S, Farquharson AJ, Williams LM, Kearney R, Arthur JR and Drew JE: High-fat diet alters gene expression in the liver and colon: links to increased development of aberrant crypt foci. Dig Dis Sci 57: 1866-1874, 2012.

142. Endo H, Hosono K, Uchiyama T, Sakai E, Sugiyama M, Takahashi H,Nakajima N, Wada K, Takeda K, Nakagama H, et al: Leptin acts as a growth factor for colorectal tumours at stages subsequent to tumour initiation in murine colon carcinogenesis. Gut 60: 1363-1371, 2011

143. Braun S, Bitton-Worms K and LeRoith D: The link between the metabolic syndrome and cancer. Int J Biol Sci 7: 1003-1015, 2011.

144. Grossmann ME, Mizuno NK, Bonorden MJL, Ray A, Sokolchik I, Narasimhan ML and Cleary MP: Role of the adiponectin leptin ratio in prostate cancer. Oncol Res 18: 269-277, 2009

145. Sharma D, Wang J, Fu PP, Sharma S, Nagalingam A, Mells J, Handy J, Page AJ, Cohen C, Anania FA, et al: Adiponectin antagonizes the oncogenic actions of leptin in hepatocellular carcinogenesis. Hepatology 52: 1713-1722, 2010.

146. Liu Z, Brooks RS, Ciappio ED, Kim SJ, Crott JW, Bennett G, Greenberg AS and Mason JB: Diet-induced obesity elevates colonic TNF- $\alpha$ in mice and is accompanied by an activation of Wnt signaling: a mechanism for obesity-associated colorectal cancer. J Nutr Biochem 23: 1207-1213, 2012.

147. Dolcet X, Llobet D, Pallares J and Matias-Guiu X: NF- $\kappa B$ in development and progression of human cancer. Virchows Arch 446: 475-482, 2005.

148. Pais R, Silaghi H, Silaghi AC, Rusu ML and Dumitrascu DL: Metabolic syndrome and risk of subsequent colorectal cancer. World J Gastroenterol 15: 5141-5148, 2009.

149. Clayton PE, Banerjee I, Murray PG and Renehan AG: Growth hormone, the insulin-like growth factor axis, insulin and cancer risk. Nat Rev Endocrinol 7: 11-24, 2011.

150. Singh P and Rubin N: Insulinlike growth factors and binding proteins in colon cancer. Gastroenterology 105: 1218-1237, 1993.

151. Giovannucci E: Nutrition, insulin, insulin-like growth factors and cancer. Horm Metab Res 35: 694-704, 2003.

152. Komninou D, Ayonote A, Richie JP Jr and Rigas B: Insulin resistance and its contribution to colon carcinogenesis. Exp Biol Med (Maywood) 228: 396-405, 2003.

153. Hart LS, Dolloff NG, Dicker DT, Koumenis C, Christensen JG, Grimberg A and El-Deiry WS: Human colon cancer stem cells are enriched by insulin-like growth factor- 1 and are sensitive to figitumumab. Cell Cycle 10: 2331-2338, 2011. 